\title{
An evaluation of EU-DEM in comparison with ASTER GDEM, SRTM and contour-based DEMs over the Eastern Mecsek Mountains
}

\author{
Edina JÓZSA ${ }^{1}$, Szabolcs Ákos FÁBIÁN ${ }^{1}$ and Mónika KOVÁCS ${ }^{1}$
}

\begin{abstract}
The availability of global coverage digital surface models (DSMs, like ASTER GDEM or SRTM) and the variation of fused models based on these (like EU-DEM) still has a great impact on scientific researches, as they provide a fairly good base dataset with a low production time and expenses. However, validation reports of the initial DSMs convinced different characteristics and errors, thus it is essential to examine these height datasets prior to application. A verifying process for EU-DEM is more important, because it has been published without a formal validation. Although the base of the EU-DEM was a corrected ASTER GDEM dataset, the visual assessment and the error statistics suggest more similarity to the SRTM DSM. This study goes further than just identifying the errors, it attempts to correct the height differences. For this reason altering the false values of the land cover and filtering the occurring noise was implemented. The geomorphometric analyses carried out as part of the verification methods propose each improved model as potential base for geomorphological studies, if they meet the certain effective resolution requirements.
\end{abstract}

Keywords: EU-DEM, ASTER GDEM, SRTM, denoising, geomorphometry, open source GIS

\section{Introduction}

In the past decade the general availability of SRTM and ASTER GDEM versions provided public domain digital height datasets ${ }^{2}$ for a growing number of earth science studies (Bolch, T. et al. 2005; Bubenzer, O. and Bolten, A.

${ }^{1}$ Department of Physical and Environmental Geography, Institute of Geography, University of Pécs, H-7624 Pécs, Ifjúság u. 6. E-mails: edina.j0zs4@gmail.com, smafu@gamma.ttk.pte. hu, monyi5@vipmail.hu

2 The SRTM and ASTER GDEM datasets are considered as digital surface models, although as stated by TAKEDA, R. and TAKEUCHI, W. (2010) DSM and digital elevation model (DEM) are not distinguished precisely in these models, because they include the height of the vegetation and buildings, but the resolution is much larger than the size of these surface elements. 
2008; DrĂguț, L. and Eisank, C. 2012; Gichamo, T.Z. et al. 2012; GrohmanN, C.H. and Sawakuchi, A.O. 2013; Seres, A. and Dobos, E. 2009; Siart, C. et al. 2009). The models are potential data sources for geomorphological researches due to the reasonable information content about the surface topography and acceptable spatial resolution, although multistep pre-processing work might be necessary (Guth, P.L. 2010; Hengl, T. and Reuter, H. 2011).

After the acquired data was distributed, several attempts were made to create a fused digital surface model (DSM) product in order to improve the reliability and applicability by taking advantage of the complementary nature of the optical and radar remote sensing technologies (Кё̈̈в, A. 2005; Karkee, M. et al. 2008; Robinson, N. et al. 2014). Recently, a continent-wide fusion dataset has been published, only for the European Union, called EUDEM (Bashfield, A. and Keim, A. 2011; EU-DEM Metadata). Assuming that the dataset is accurate and reliable enough, it might fill a data gap in this field. Different characteristics of the applied source models and the steps of the data compilation significantly affect the quality of the final DSM product, so this paper focuses on exploring these effects and the applicability of the EU-DEM. It is necessary to reveal the specifications of the DSM and also analyse the most commonly occurring errors, in order to be clear about how accurate the results obtained using this model could be.

While the data gathering was carried out in two weeks for the SRTM, the creation of satellite images for the ASTER GDEM required years. Therefore only the former model provides well-defined, immediate snapshot of the Earth's surface. Furthermore, the quality of the GDEM varies in each region, as the quality of the source images and the number of available scenes for the elevation data preparation can be different (ASTER GDEM Validation Team 2009; FArr, T.G. et al. 2007; Frey, H. and PAUl, F. 2012; UrAI, M. et al. 2012). Another known issue of the models is the overall negative bias for ASTER GDEM and positive bias for SRTM in bare surface areas (ASTER GDEM Validation Team 2009, 2011; Forkour, G. and MaAthuis, B. 2012; Mukherjee, S. et al. 2013). An appearance of the artefacts - 'residual clouds', 'bumps', 'pits', 'mole runs' on GDEM, voids due to radar shadow on SRTM - is also a well-known problem of the models. All these were taken into consideration during the fusion process of EU-DEM by carefully removing the data with possible error and applying a terrain slope-dependent, weighted averaging method for the compilation (BAshfield, A. and Keim, A. 2011).

Although, GDEM and SRTM versions have been studied in different regions of the Earth (e.g. Hirano, A. et al. 2003; Jacobsen, K. and Passini, R. 2009; Li, P. et al. 2012; Reuter, H.I. et al. 2009; Szabó, G. and Szabó, Sz. 2010; Szabó, G. et al. 2013; Winkler, P. et al. 2006; Zhao, S. et al. 2011), as a part of this study a quality assessment and comparison of the ASTER GDEM V2 and SRTM V4.1 is also applied to review the specifications of the models over the 
Eastern Mecsek Mountains. Previous papers reported better results for the SRTM (Frey, H. and Paul, F. 2012; Suwandana, E. et al. 2012), but the validation report and newer studies convinced the improvements of GDEM V2 (ASTER GDEM Validation Team 2011; SADEQ, H. et al. 2012; UrAI, M. et al. 2012). As the DEM-based automated or semi-automated landform classification, geomorphometric analysis is a prosperous subdivision of geomorphological researching (DrăguȚ, L. et al. 2011; DrăGuț, L. and Eisank, C. 2011; SAadat, H. et al. 2008; van Asselen, S. and Seijmonsbergen, A.C. 2006), thus it is necessary to obtain proper data sources. If the DSMs are corrected with certain pre-processing steps, it is assumed that they could become a potential elevation database for further geomorphological researches in this area.

\section{Study area}

The study is carried out on a $350 \mathrm{~km}^{2}$ large part of the Eastern Mecsek Mountains and its northern and southern foreland, located between 591,000; 800,00 (SW) and 605,000; 105,000 (NE) EOV coordinates (Figure 1).

From a geomorphological point of view, the area is divided into a low mountainous and hilly and a piedmont region, the elevation ranges from approx. $139 \mathrm{~m}$ up to 682 at Zengö as the highest peak. Landforms of the investigated area are determined by geological structure and palaeoclimatic conditions. Thus, before the GIS-based analyses it is required to overview the general geologic settings and landform evolution.

Within geological structure of the study area three main units can be distinguished. The central part of the study area is a low mountainous region builted up by Mesozoic marine, fluvial and lacustrine sediments and crossing rift-type volcanic rocks. The Upper Triassic Karolinavölgy Sandstone is the oldest formation that can be found on the western boundary of the area. It is overlain by Liassic fluvial-lacustrine-palustrine sediments with interbedded paralic coal-swamp deposits (Mecsek Coal Formation). The opencast coal mining affected the elevation values over the study area therefore it was taken into consideration during calculations. The rapid subsidence of Mecsek half graben in Early and Middle Jurassic indicates increasing carbonate content and marl with limestone intercalations become characteristic (e.g. Hosszúhetény Marl F.). Siliceous and carbonate deep-sea sedimentation developed in the second half of the Jurassic. The Early Cretaceous basaltic magmatism penetrated the Jurassic layers and a basalt-tephrite-phonolite series occurs (Mecsekjános Basalt F.). It is covered by conglomerate and sandstone deposits (HAAs, J. 2012). A radial horst range is dominant in this part of the study area and it has been dissected by a complex, dense erosional valley network due to the erodibility and impermeability of Mesozoic rocks (Ádém, L. et al. 1981). 


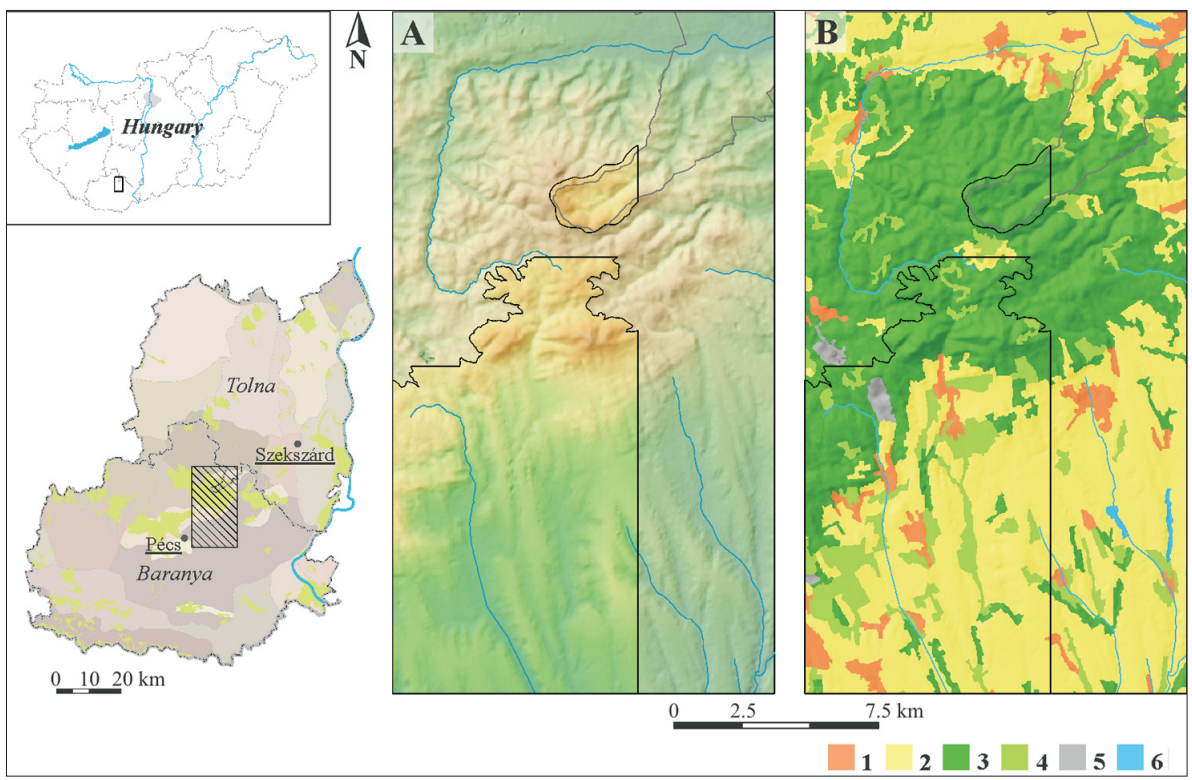

Fig. 1. Location of the study area (also showing the boundaries of micro regions* and Natura 2000 SCI areas**) and its EU-DEM image (A) overlying highlighted reference DEMs and the aggregated land cover categories of CLC2006 (B). $-1=$ urban and associated areas; $2=$ areas considered as bare surface; 3 = forests; 4 = permanent crops, shrub, semi natural and agricultural area, dumpsites; $5=$ mineral extractions; $6=$ water bodies * http://www.novenyzetiterkep.hu/?q=magyar/node/407

** http://www.eea.europa.eu/data-and-maps/data/natura-4\#tab-gis-data

The second main unit built-up by Miocene alluvial, marine and lacustrine sediments that encompasses the higher central part. Northern side of this unit is characterized by chiefly older (Szászvár Formation), while the southern by younger (Leitha Limestone F.) Miocene strata. As the Mecsek was an island in the Late Miocene, and the long-life Lake Pannon developed its sediments, which can be observed on both sides of Mecsek Mountains. (Nagymarosy, A. and Hámor, G. 2012). These parts of the study area are characterized by a lower hilly surface.

The third unit consists of a young aeolian loess series intercalated by paleosoils (Lovász, Gr. 1977; PÉCsi, M. et al. 1988) on the top of the interfluves and proluvial deposits in the dry valleys and on the slopes. The Mecsekalja region is characterised by fragmented, lowering hills with general gentle sloping to south, while steeper slopes and deeper valleys can be found on Mecsekhát (the northern section).

The landscape and landform evolution of the study area was described as a classical pedimentation process that formed a typical piedmont surface. This piedmont sensu Pécsi, M. (1963) is generally younger than the Pannonian layers that were cut with a gentle plain, but older than Quaternary erosional 
valleys with fluvial terraces. On the southern slopes of Mecsek Mountains. different pre-pedimentation denudation levels were observed ( $c f$. Figure 7 in PécsI, M. 1963 p. 199 and Figure 3a in Pécsi, M. et al. 1987, p. 42) that was formerly described as Middle and Late Miocene abrasion terraces or etchplains (Kovács, I.P. et al. 2013). Formation of the Mecsekalja piedmont surface started after retreating Lake Pannon approx. 7 Myr ago (Magrar, I. et al. 1999) and continued in Early Pliocene under arid steppe climate (SCHWEITZer, F. 1997; SEBE, K. et al. 2008). On Mecsekalja a dislocation zone (neotectonic fault system) developed that results a subsidence from Okorág towards Pécs, Ellend and Bóly, where basins were evolved as tectonic subsidence moved eastward. On Western Mecsekalja Pécs basin dissected the original piedmont surface thus it changed the valley and water network considerably. Obsequient valleys sloping to North have cut deep into Upper Miocene and Pliocene beds (FÁbIán, Sz.Á. et al. 2005; SeвE, K. et al. 2008), while subsequent valleys captured consequent streams. These river captions characterize the eastern and east-southern part of Pécs basin, and Eastern Mecsekalja is also affected by the processes.

The study area consists the last remain of original piedmont surface on the western section of Eastern Mecsekalja, however the traces of neotectonic subsidence (e.g. river captures, valley asymmetry) have already appeared (Kovícs, M. 2013). Beyond main goal of this paper, a GIS-based geomorphological analysis was also attempted to identify these relict, hardly modified classical piedmont surfaces.

Nowadays, the area has only a sparse settlement network because of the large nature reserves and Natura 2000 areas of the Mecsek Mountains region. As a result of the strict protection, a wide forested area of about $145 \mathrm{~km}^{2}$ is present in the study site, influencing the elevation values of the DSMs. The extensive agricultural fields represent the other relevant land cover category.

The low mountainous and piedmont topography completed with land cover conditions mentioned above seems appropriate for the chosen study showing the typical challenges related to the application of satellite-based DSMs (VÁGó, J. and Hegedús, A. 2011).

\section{Methods and materials}

The components are organized into a flow chart for a better perspicuity, as the quality assessment process and the attempted error correction consist of several steps (Figure 2).

Since the topic of satellite-based DSMs has been studied, it is essential to review the available official validation reports and other papers before further examinations. In addition, for the GDEM a QA file (NUM file) is also available, which provides information about the amount of stereo image 


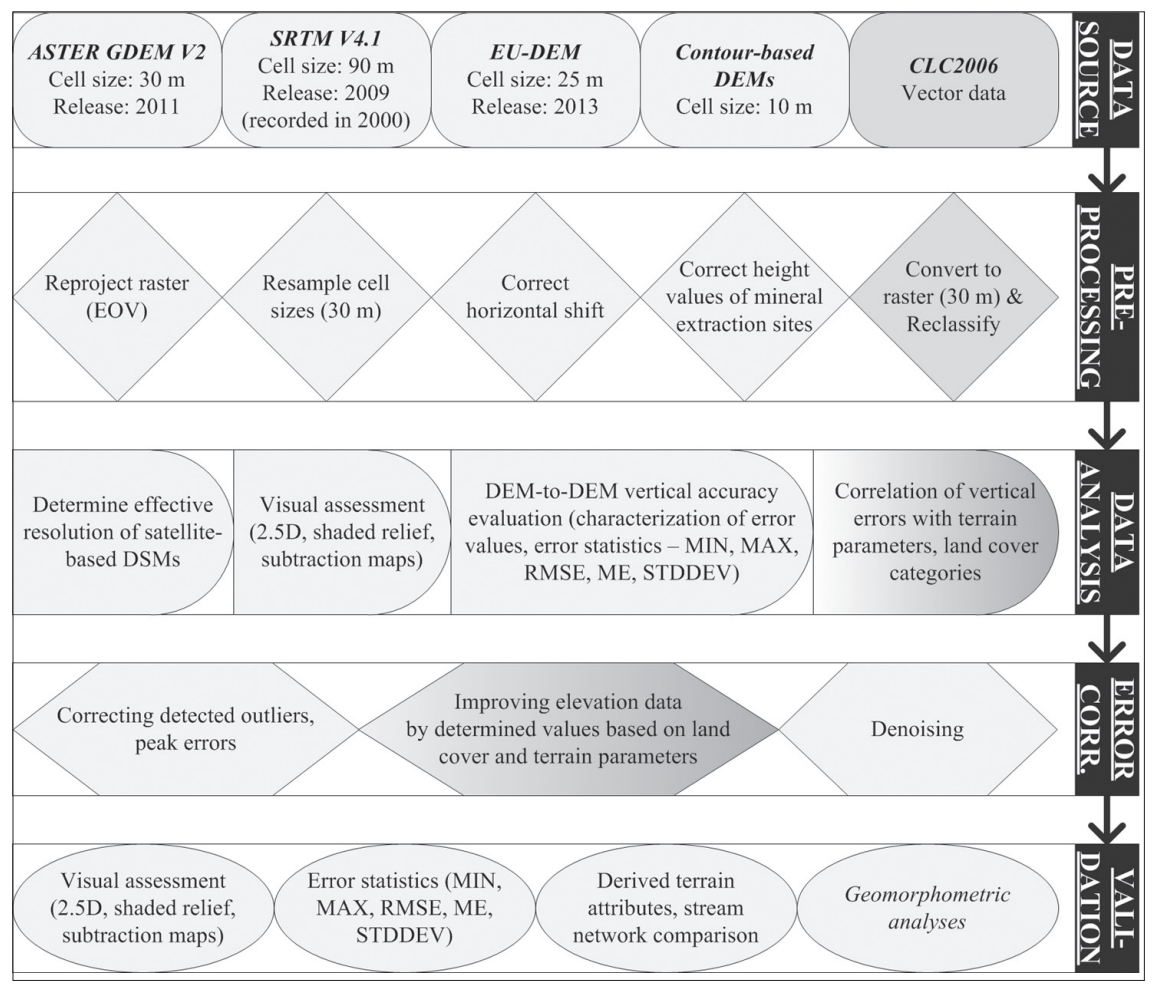

Fig. 2. The flow chart of the study

pairs used for the determination of the elevation values ${ }^{3}$. The ASTER GDEM Validation Team (2011), URAI, M. et al. (2012) proved that a higher number of 'stacks' resulted in better height values, and the concept of the EU-DEM creation is also based on this characteristic.

During the pre-processing the elevation datasets were converted to a common projection and cell size, the horizontal misfit (ASTER GDEM Validation Team 2011; FREY, H. and PAUL, F. 2012) was corrected and the cells of mineral extraction sites were reinterpolated to avoid their misleading errors.

The data analysis included computing the effective resolution of the models (Guth, P. L. 2010), and visualizing the representation of the surface and errors. An important task was the thorough examination of the vertical accuracy. According to Mukherjee, S. et al. (2013) the assessment of the models based on a few sample points is not a proper method. Similar to the cited research surface-to-surface comparisons of the satellite based DSMs and the contourbased DEMs were performed and the error statistics were calculated. Based on

${ }^{3}$ This is also called 'stacks' and it is understood as the number of valid elevation data. 
previous studies (Frey, H. and PAUL, F. 2012; Szabó, G. et al. 2013; Zhao, S. et al. 2011) the correlation of height errors with terrain characteristics and land cover types was assumed and therefore examined. An attempted method was applied to improve the DSMs. The outstanding errors were corrected and the whole dataset was modified according to the topography and land cover, in order to make the models more representative regarding the real surface. Finally, a denoising algorithm was implemented (STEVENSON, J.A. et al. 2010).

Due to the modifications the accuracy of the resulted models required retesting. For the validation both error statistics and characteristics of the digital surface relevant to geomorphological researches were examined. The geomorphometric maps of the study area were generated based on the Topographic Position Index of WeIss, A. (2001).

It is important to emphasize that all steps were carried out using GNU GPL (General Public License), open-source software including GRASS GIS 6.4.3 (http://grass.-osgeo.org/), SAGA GIS 2.1.0 (http://saga-gis.org) to create and process the datasets and $\mathrm{R}$ (http://www.r-project.org) to perform the statistical analyses. The spgrass 6 package (BIVAND, R. 2013) provided the R - GRASS interface, making it available to analyse the maps' statistics with the built-in and user-defined functions of $R$, and create graphs representing the results.

\section{The EU-DEM V1 dataset}

The EU-DEM is a middle-precision surface model with a horizontal resolution of about $25 \mathrm{~m}$, published in October 2013. It was created by an automated data fusion of improved ASTER GDEM data with SRTM data, using a weighted averaging approach. Substantial steps of the data preparation was the removal of the GDEM's elevation values where the number of scenes was less than 5 , cloud cover caused errors or extremely differing height values occurred, and the filling of the voids with SRTM data. The concept of the model was to combine the advantages of both digital surface models with additional improvement by a new hydrography dataset and NEXTMap data (BASHFIELD, A. and KeIm, A. 2011). The DSM is a realisation of the Copernicus programme, managed by the European Commission, DG Enterprise and Industry. The EU-DEM is available in $5^{\circ} \times 5^{\circ}$ tiles from the website of the European Environment Agency ${ }^{4}$ (EEA) or the European Commission ${ }^{5}$. As the data was provided without a formal validation, prior information about the horizontal and vertical accuracy has not been available yet (EU-DEM Metadata).

\footnotetext{
${ }^{4} \mathrm{http}: / /$ www.eea.europa.eu/data-and-maps/data/eu-dem\#tab-european-data

${ }^{5}$ http://epp.eurostat.ec.europa.eu/portal/page/portal/gisco_Geographical_information_ maps/geodata/digital_elevation_model
} 
The Shuttle Radar Topography Mission acquired interferometric radar data for approx. 80 percent of the Earth in February 2000, using dual radar antennas (FARR, T.G. et al. 2007). The Consortium for Spatial Information (CGIAR-CSI) of the Consultative Group for International Agricultural Research (CGIAR) made available a post-processed, seamless, void-filled and complete elevation

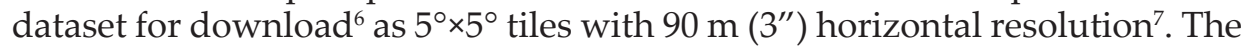
vertical error of the SRTM DSM is reported to be less than $16 \mathrm{~m}$, although accuracies are varying by continent and region (Rodriguez, E. et al. 2005; FARR, T.G. et al. 2007).

\section{The ASTER GDEM V2 dataset}

The Ministry of Economy, Trade and Industry (METI) of Japan and the National Aeronautics and Space Administration (NASA) developed GDEM jointly that covers 99 percent of the land surface (ASTER GDEM Validation Team 2009). The basic difference from SRTM is that the ASTER GDEM was produced by extracting elevation values from a large amount of scenes collected between 2000 and 2010 by the Advanced Spaceborne Thermal Emission Reflection Radiometer (ASTER) on NASA's Terra spacecraft using nadir- and aft looking infrared cameras (ASTER GDEM Validation Team 2011; URAI, M. et al. 2012). The dataset is available from multiple websites (e.g. Japan Space Systems ASTER GDEM webpage ${ }^{8}$ ) as $1^{\circ} \times 1^{\circ}$ tiles, with $30 \mathrm{~m}$ cell size. The validation studies provide different accuracy values in different regions of the globe using different ground truth data, but in all the absolute vertical accuracy is reported to be approx. $17 \mathrm{~m}$ (ASTER GDEM Validation Team 2011).

\section{The reference DEMs}

The contour-based DEM of two sites over the study area was interpolated in SAGA GIS using the Triangulation method with $10 \mathrm{~m}$ cell size. The extent of these areas is approx. $130 \mathrm{~km}^{2}$. The created elevation models were used to represent the ground-truth values for the error estimation methods after downsampling to $30 \mathrm{~m}$ in GRASS. Manually digitising the contour lines and elevation points from the EOTR (Unified National Map System) topographic

\footnotetext{
${ }^{6} \mathrm{http}: / /$ srtm.csi.cgiar.org/SELECTION/inputCoord.asp

${ }^{7} \mathrm{http}$ ://www.cgiar-csi.org/data/srtm-90m-digital-elevation-database-v4-1

${ }^{8} \mathrm{http}$ ://www.jspacesystems.or.jp/ersdac/GDEM/E/index.html
} 
maps in scale of 1:10,000 provided the most accurate database at the lowest cost for the area. As stated by Engler, P. and MéLYKúti, G. (2000) and WinkLer, P. et al. (2007) the terrain information contents of the maps meet the accuracy requirements of the T.1. Regulation, thus the accuracy of created DEMs is considered adequate to provide an acceptable quality assessment of the abovementioned satellite DSMs and the fused EU-DEM dataset.

\section{The CORINE Land Cover 2006 database}

The seamless vector database of CLC2006 (BüTTNER, G. et al. 2012) was downloaded from the EEA's site ${ }^{9}$ and converted into a $30 \mathrm{~m}$ resolution raster dataset. Analysing the impact of the land cover on the elevation models was executed on 6 aggregated categories (Figure 1b), that was based on the height of the features (vegetation, buildings) or the potential error of the elevation values (mineral extraction, water bodies).

\section{Results and discussion}

\section{Data preparation}

All analysed satellite-based DSMs were projected to the Hungarian Unified National Projection (EOV) from lat/long (SRTM and ASTER GDEM) and ETRSLAEA (EU-DEM) projections ${ }^{10}$. For the comparison the models were upsampled or downsampled from their native resolutions to the common $30 \mathrm{~m}$ cell size - either as part of the reprojection process, or using the resample tool in GRASS. The univariate statistics (minimum, maximum, mean, standard deviation) confirmed that the resampling did not affect the data content significantly (Table 1).

Table 1. The univariate statistics of the models before (OR) and after resampling (RS)

\begin{tabular}{l|r|r|r|r|r|r|r|r}
\hline \multirow{2}{*}{ Indicator } & \multicolumn{3}{|c|}{ Minimum $(\mathrm{m})$} & \multicolumn{2}{c|}{ Maximum $(\mathrm{m})$} & \multicolumn{2}{c|}{ Mean } & \multicolumn{2}{c}{ STDDEV } \\
\cline { 2 - 9 } & OR & \multicolumn{1}{c|}{ RS } & OR & RS & OR & RS & OR & \multicolumn{1}{c}{ RS } \\
\hline ASTER GDEM & 73.0 & 83.0 & 690.0 & 689.2 & 259.4 & 272.0 & 92.8 & 95.6 \\
SRTM & 123.0 & 124.8 & 680.0 & 680.0 & 257.4 & 269.8 & 91.9 & 94.8 \\
EU-DEM & 123.4 & 123.7 & 677.4 & 677.4 & 269.5 & 270.0 & 94.6 & 94.6 \\
ref. DEMs & 138.8 & 138.8 & 680.0 & 679.8 & 273.2 & 273.4 & 101.7 & 101.8 \\
\hline
\end{tabular}

\footnotetext{
${ }^{9} \mathrm{http}$ //www.eea.europa.eu/data-and-maps/data/clc-2006-vector-data-version-2\#tab-metadata

${ }^{10}$ It has to be noted that the models were created using different vertical datums and geoids, that also causes the deviation of the elevation values, but based on previous information (KenYeres, A. et al. 2010; Winkler, P. et al. 2006) the height differences are much smaller than the reported vertical accuracy of the models.
} 
The location of three peaks - Zengö, the middle peak of the Hármashegy and Dobogó was compared to check the horizontal misfit of the models. Using the displacement values the DSMs were moved, and the height errors for every new location were calculated by subtracting the models from the reference DEMs. The suitable horizontal offset was determined by checking spatial distribution of the errors that still suggests horizontal shift, and examining the absolute mean error and standard deviation of the errors. The difference in the East-West direction was similar - around $70-80 \mathrm{~m}$ to the East, while the shift in the North-South direction varied from 12 to 42 meters to the North.

\section{Quality assessment}

The ASTER GDEM Validation Team (2011) reported that the error values decrease significantly as the 'stack' number increases between 1 and 10 and there is only little improvement over 15. According to Bashield, A. and Keim, A. (2011) the cells with less than 5 'stacks' were removed from the EU-DEM during the preparation process. The examination of the QA file showed that over the study area the cells with 'stacks' less than 10 is not reaching 1 percent of the total area, and 91.6 percent of the values were determined from more than 16 'stacks'.

The mentioned validation reports and independent studies (Guth, P. L. 2010; ASTER GDEM Validation Team 2009, 2011) revealed that although the GDEM V2, GDEM V1 and the full-resolution SRTM has approximately $30 \mathrm{~m}$ spacing of postings none of the DSMs have $30 \mathrm{~m}$ horizontal resolution. This also suggests that the EU-DEM fused model has a lower horizontal resolution as well. The effective resolutions (Table 2) were determined using the method of GuTH, P.L. (2010). The reference DEMs were resampled to 10 different resolutions (10 to $100 \mathrm{~m}$ ) and the mean slope values derived from every model were compared.

Table 2. The effective resolution of the DSMs

\begin{tabular}{l|c|c|c}
\hline \multicolumn{1}{c|}{ Indicator } & $\begin{array}{c}\text { Spacing } \\
(\mathrm{m})\end{array}$ & $\begin{array}{c}\text { Resolution (former } \\
\text { studies }^{*}(\mathrm{~m})\end{array}$ & $\begin{array}{c}\text { Resolution (in this paper) } \\
(\mathrm{m})\end{array}$ \\
\hline ASTER GDEM & 30 & $\sim 71$ & $\sim 56$ \\
SRTM & 90 & $\sim 97$ & $\sim 92$ \\
EU-DEM & 25 &.. & $\sim 68$ \\
\hline
\end{tabular}

* There are different values published. The values presented were calculated based on the standard deviation of downsampled non-LiDAR DEMs and the DSMs over test areas in Japan and West Virginia (ASTER GDEM Validation Team 2011). .. means no data.

The shaded relief maps (Figure 3) and 2.5D visualization (NVIZ) are simple but effective tools to obtain preliminary information about the quality of the datasets. The EU-DEM looks well-smoothed in NVIZ, which was expected 


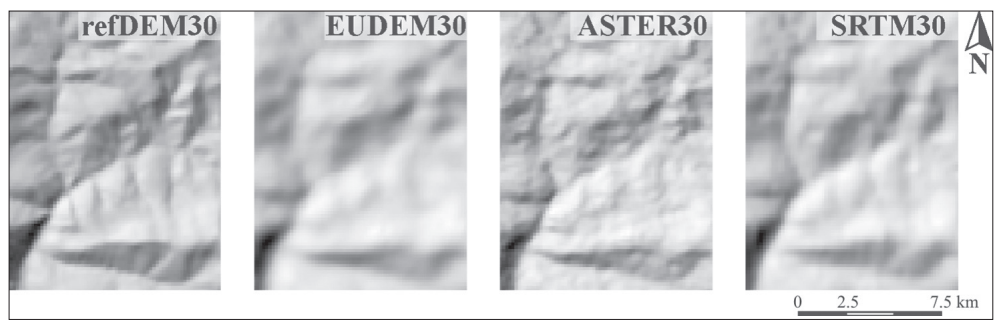

Fig. 3. Shaded relief maps of the models showing the Zengö and the upper parts of the Vasas-Belvárd stream's valley

according to the production method. However, the strong smoothing resulted in a loss of surface details, as it is shown on the 'blurry' shaded relief map.

The noise of the ASTER GDEM is conspicuous on the 2.5D map and on the shaded relief map also, suggesting necessary denoising. The $2.5 \mathrm{D}$ view of SRTM visually indicates a relatively correct representation of the surface, which is confirmed by the hillshading, too. The subtraction maps provided the numerical data for the further error analysis, but they were useful to check the spatial distribution of positive and negative errors with the proper colour table (see figures at the validation). As expected, generally the DSMs are above the reference datasets in the forested low mountainous parts and in the valleys (PAUL, F. 2008), while under or near to the real surface on the piedmont. Although, the error values on the subtraction map of the ASTER GDEM show a higher variation.

First of all the analysed models were compared to each other by determining their correlation. From the satellite-based DSMs the SRTM and EU-DEM shows the strongest correlation, while compared to the reference DEMs the SRTM has the highest and the ASTER GDEM the lowest value. The correlation of the height differences (Figure 4) show a strong positive association, the highest value occurs between the SRTM and EU-DEM.

The error statistics ${ }^{11}$ - with no respect to terrain parameters or land cover types - give a general overview for the study area. The mean absolute error (MAE), the standard deviation of errors (SD) and the root mean square error (RMSE) are the highest in case of the ASTER GDEM, although the range of errors is the lowest. This indicates that higher number of cells has vertical error. The range of errors is the highest for SRTM, suggesting that outstanding errors are present in the model. Aguilar, F.J. et al. (2007) declare that outliers can corrupt the true statistical distribution of errors, thus the ' $3 \sigma$ rule' i.e. three times the standard deviation was applied to remove errors. The $3 \sigma$ RMSE

\footnotetext{
${ }^{11}$ Height differences were determined by subtracting the reference DEMs from the satellitebased DSMs, thus negative values represent areas where the reference models have higher elevation values.
} 


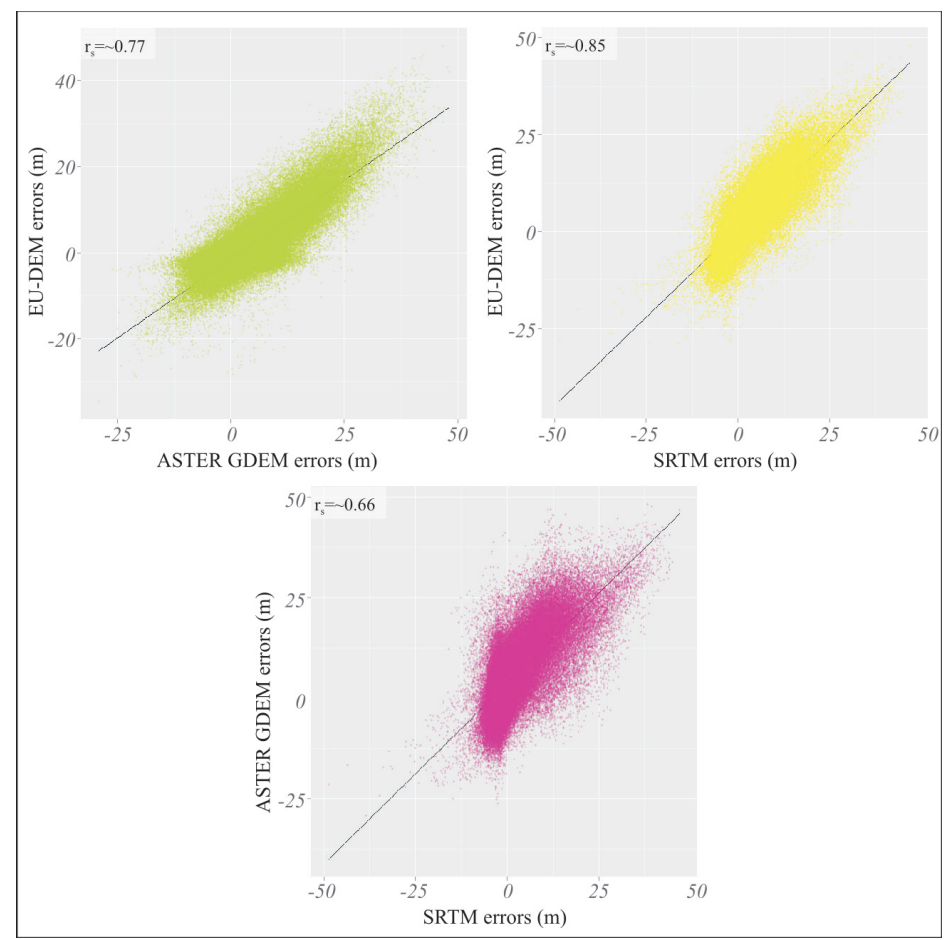

Fig. 4. Simple scatter plots between the errors of the satellite-based DSMs

suggests the significance of outstanding errors, but as it is shown by the new RMSE values the outlier correction method was not able to remove these errors (Table 3). Despite an expected consequence of the applied corrections, the EU-DEM has not got the lowest error statistic values.

Examining the frequency of errors also showed that the GDEM has more cells with error. The high kurtosis of SRTM and EU-DEM proves that outliers and significant vertical errors affect a small percentage of the cells. The positive 'skewness' indicates that the models are overall above the ground truth DEMs.

The accuracy assessment was also implemented by segmenting the models based on land cover types to analyse the difference of errors in bare

Table 3. The change in RMSE values

\begin{tabular}{|c|c|c|c|c|}
\hline Indicator & $\begin{array}{c}\text { Initial } \\
\text { RMSE (m) }\end{array}$ & $\begin{array}{l}\text { Initial } 3 \sigma \\
\text { RMSE }(\mathrm{m})\end{array}$ & $\begin{array}{l}\text { Outliers corr. } \\
\text { RMSE }\end{array}$ & $\begin{array}{l}\text { Final corr. } \\
\text { RMSE }\end{array}$ \\
\hline ASTER-GDEM & 10.1 & 8.9 & 10.1 & 6.1 \\
\hline SRTM & 7.3 & 5.8 & 7.3 & 5.3 \\
\hline EU-DEM & 7.8 & 6.6 & 7.8 & 6.0 \\
\hline
\end{tabular}


surfaces and forested areas. The correlation of the errors to terrain parameters (elevation, slope, aspect) was also checked.

Over the forested area the range of errors is the same as the overall value, while in the case of the bare surface it is much smaller, suggesting that the outliers appear in the forested parts. This is also convinced by the small difference between the RMSE and 3бRMSE of the bare regions.

Looking at just the error statistics of the bare surface the ME of the ASTER GDEM is positive, showing that the GDEM have a significant number of values above the reference DEMs, while the negative ME of the SRTM and EU-DEM indicates that these models slightly underestimate the elevation values. This difference can also be observed in the forested areas, as the MAE and ME of ASTER GDEM is higher with 2-3 metres. Although, in the latter case it is also related to the acquiring method, as the SRTM represent the elevations within the vegetation and the GDEM provided 'first return' data from the canopy top (HoFToN, M. et al. 2006; LI, P. et al. 2012). The absolute relief on the reference DEMs' area is only 542 metres, thus significant correlation of the errors was neither expected nor found. The same was determined in case of the slope gradiens.

Former studies suggest that the slope aspect can affect the accuracy of elevation values (Frey, H. and Paul, F. 2012; Szabó, G. 2011; Szabó, G. et al. 2013). The proportion of aspect categories was approx. equal for the forested, low mountainous regions. However, as the land cover types representing bare surface occur over the piedmont area southern slopes are dominated, and because of the almost meridional valleys the eastern and western directions are also significant. Figure 5 shows a slight fluctuation of the error values in different directions, thus the effect of the aspect is considered negligible. On the other hand, in the forested areas the fluctuation is more noticeable: the highest differences occur in the northern directions.

\section{Error correction}

The first step was to remove the outlier errors, which could degrade the results of the further corrections. Before any complex correction algorithm the r.fill.dir command was used to remove the depressions from the models. The afterwards implemented method ${ }^{12}$ was published by Neteler, M. (2005) and adopted to the characteristics of the models. The mean and standard devia-

${ }^{12} \mathrm{MAP}=$ ASTER GDEM/SRTM/EU-DEM g.region rast=\$MAP - p r.neighbors $\$$ MAP out $=\$ M A P . m e a n 3$ meth=average size $=3$ r.neighbors $\$$ MAP out= $\$$ MAP.mean 5 meth=average size $=3$ r.neigbors $\$$ MAP out $=\$ M A P$. stddev3 meth $=$ stddev size $=3$ r.neigbors $\$ M A P$ out $=\$$ MAP.stddev 5 meth $=$ stddev size $=3$ r.mapcalc,$\$ M A P . f i l t=i f(\$ M A P>=280$, if $($ abs $(\$ M A P$ - \$MAP.mean3) > 1.5* \$MAP.stddev3, \$MAP.mean3, \$MAP), if(abs(\$MAP - \$MAP.mean5) $>1.5$ * \$MAP.stddev5, \$MAP.mean5, \$MAP) (NeTELER, M. 2005). 


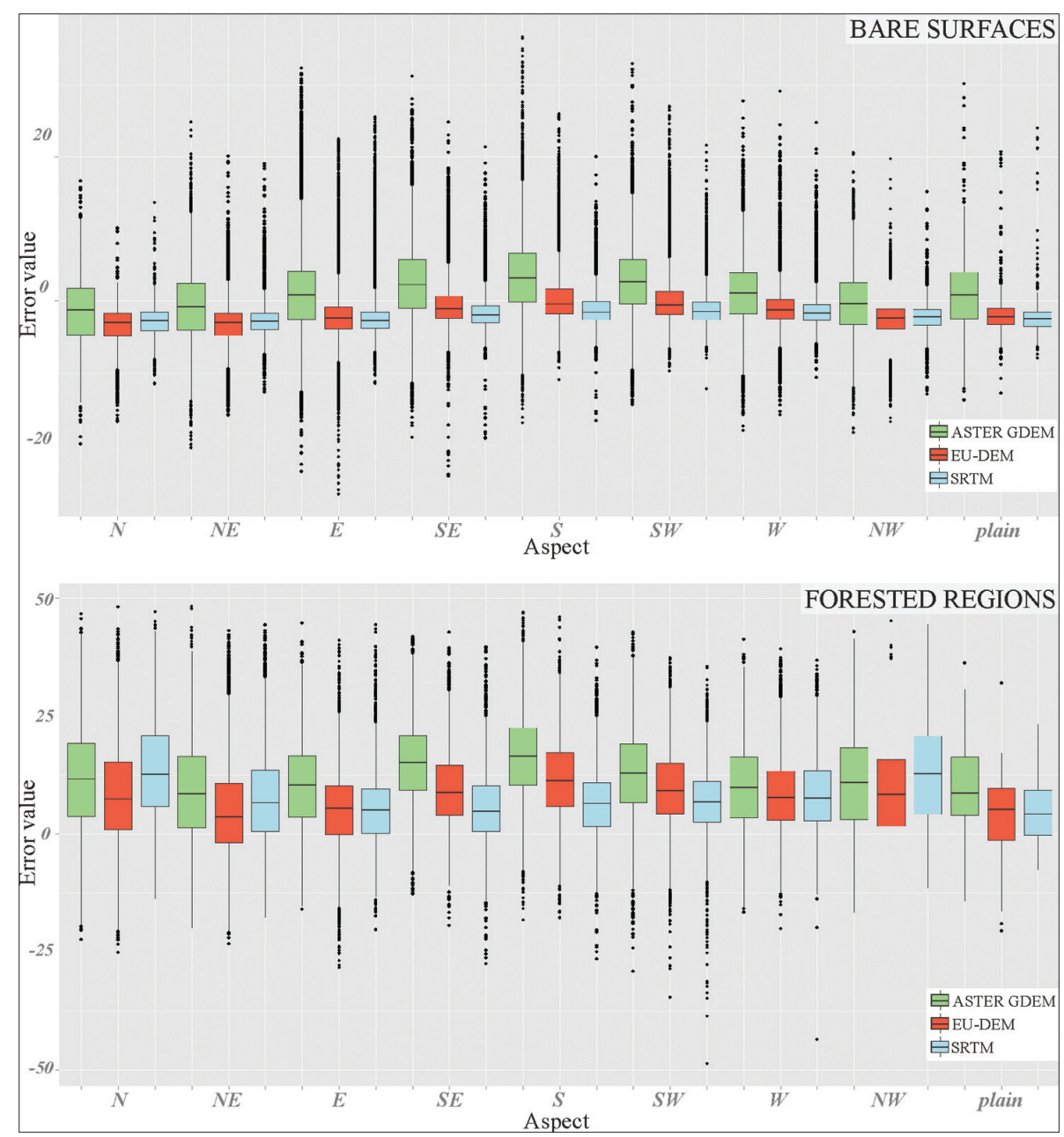

Fig. 5. The connection between the values of error and slope aspect over bare surfaces and forested regions

tion values were used to determine whether a cell deviates 'enough' to be considered as outlier, and, if so, the method replaces it with the mean value. Major changes in the original method were the use of lower standard deviation limit and different neighbourhood sizes based on the elevation. In the case of the ASTER GDEM 22,500 cell values were involved in the correction, while less than 4,000 cells were modified on the other two models. However, removing the outliers affected the SRTM the most, as the ME, STDDEV, range of the errors and the difference between the normal and $3 \sigma$ RMSE were also reduced. 


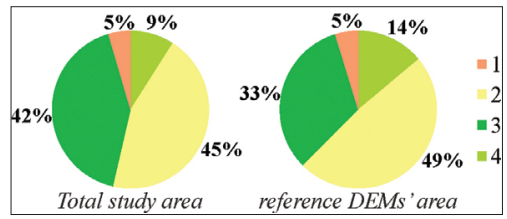

Fig. 6. Distribution of land cover categories. $-1=$ urban and associated areas; $2=$ areas considered as bare surface; 3 = forests; 4 = permanent crops, shrub, semi natural and agricultural area, dumpsites

To eliminate the effect of the land cover categories mean difference values, determined over the reference DEMs region, were subtracted from the DSMs. This was possible because the distribution of the different categories is almost identical for the total study area and the reference DEMs (Figure 6), so the values were considered representative. According to the previously stated correlation results the continuous forest areas, in regions with higher slope values, were subdivided based on aspect categories.

For smoothing the noises, residual errors on the models, Sun's denoising algorithm (Sun, X. et al. 2007; STEvenson, J.A. et al. 2010) was applied. The executable file runs from command line and manages the models out of GRASS GIS, as a 'xyz' dataset. Setting the parameters (threshold and number of iterations) give a good control over the method to produce an acceptable result. The parameter values ( 7 iterations and 0.98 threshold value) were determined based on the recommendations of the above mentioned studies. Although it should be mentioned, that tuning the values more precisely could lead to even better results. The $2.5 \mathrm{D}$ view of the DSMs shows a much smoother image. The most outstanding change was experienced on the ASTER GDEM.

As the last modification the models were smoothed with an average filter (by $3 \times 3$ neighbourhood matrix) in order to avoid steps at the border of the land cover categories.

\section{Validation}

The repeated visual assessments confirmed the reduction of errors, noise on the models. The shaded relief map of ASTER GDEM shows that the stronger smoothing algorithm affected the information content of the model. The subtraction maps also show a significant improvement (Figure 7. A, B). The ridges and valleys remained erroneous, as a result of the earlier mentioned characteristics of the models.

The RMSE (Table 3), MAE and ME values decreased the most in the case of the GDEM, while the STDDEV shows significantly lower values for the GDEM and SRTM. A notable change, related to the correction of outliers, is that the range of errors on the SRTM decreased by 25 percent. The cells with less than $1 \mathrm{~m}$ error are 41 percent on the SRTM, 37 percent on the EUDEM and only 27 percent on the ASTER GDEM.

The accuracy of slope and aspect as terrain derivatives was checked. The slope values were reclassified according to the agricultural suitability 


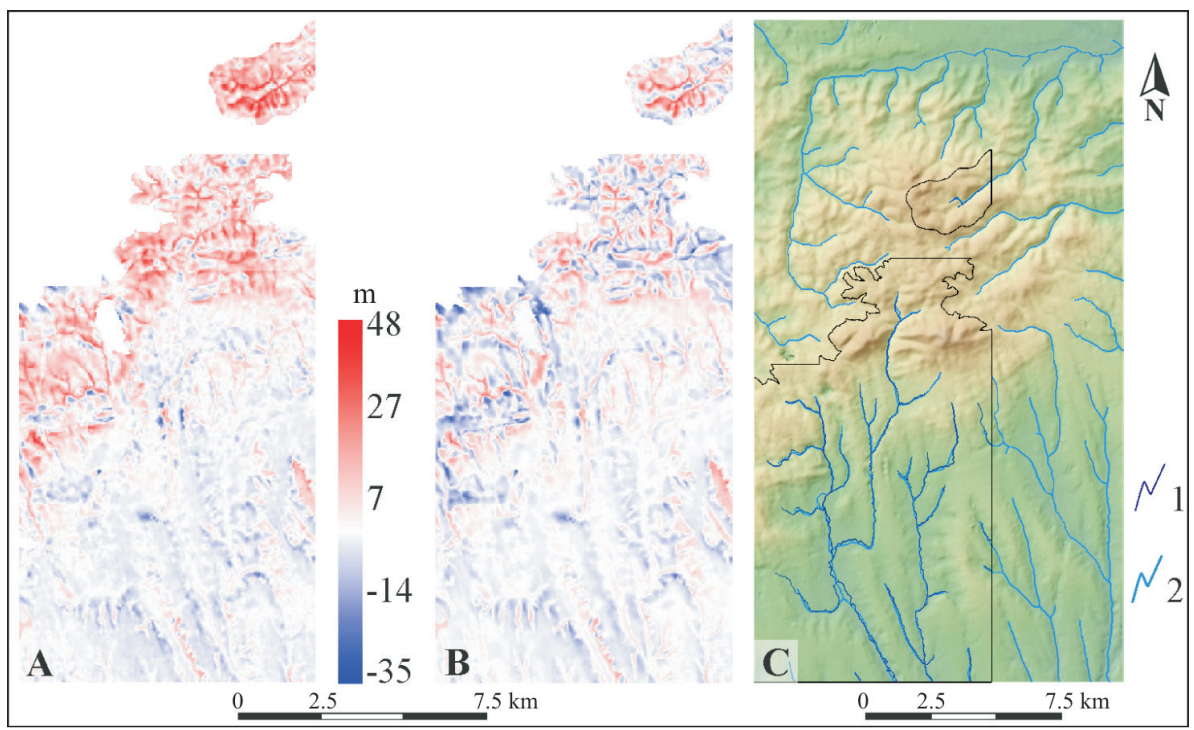

Fig. 7. The subtraction maps of the EU-DEM before (A) and after (B) the corrections and the derived stream network of the reference DEMs and the EU-DEM (C). - $1=$ stream line on reference DEMs, 2 = stream line on EU-DEM

(PÉCSI, M. 1985). Generally, all of the DSMs derivatives look similar to the ones created from the reference DEMs. The slope and aspect categories overlap best on the ASTER GDEM and EU-DEM, although the mean slope value of SRTM is closer to the reference DEMs'. The differences are partly related to the smoothing used at the production of the DSMs, and the original cell sizes.

As a validation step the stream network for at least $1 \mathrm{~km}^{2}$ watersheds of the study site was computed with GRASS GIS (Figure 7. C). Although the length - based on the cell numbers - and location of the streams is almost identical, the correlation between the different stream networks is low. 77 percent of stream cells from SRTM stream lines, 71 percent from EU-DEM and 64 percent from GDEM stream line cells are within a $100 \mathrm{~m}$ buffer zone of the reference DEMs stream lines.

\section{Geomorphometric map}

The geomorphometric analysis had two purposes. First, it can be considered as a method to validate the corrected EU-DEM, but it also provides additional information for the geomorphological issues of the study area. 
The geomorphometric map was generated by the TPI method, following the steps described by WeIss, A. (2001) and Jennes, J. (2006). This approach classifies the cells of the DEM based on the average elevation of their neighbourhood. It is calculated by subtracting the averaged models of different neighbouring cell matrices from the original. For the geomorphometric map two versions (averaged on $11 \times 11$ and $33 \times 33$ cells) of standardized TPI maps were combined, and the landforms were classified based on the standard deviation and slope values. The latter was set as 2.5 degrees, based on the findings of PÉCSI, M. (1963). The map is generalized containing only 10 landform types, but it fits the resolution of the input elevation dataset.

Figure 8 shows the valley network, mountain top region and the piedmont-like surfaces to get a better view of these more important forms. The plain surfaces between 180-280 meters were selected as potential parts of the Eastern Mecsek Mountains' piedmont region. The elevation level was also defined according to the previous results of PécsI, M. (1963).

The TPI-based landform classification verified the radial horst ranges surrounding the highest mountain top regions (Dobogó, Hármashegy and Zengö). The narrow, dense valley network of the central part of the study area fits the geological settings. The sharp bendings of the Völgységi Stream are clearly visible on the calculated landforms map, showing a strong correlation with the geological structures and tectonic lines.

The relict landforms of the Mecsekalja piedmont region were also found on the geomorphometric map. Stretching the patches of the piedmont-

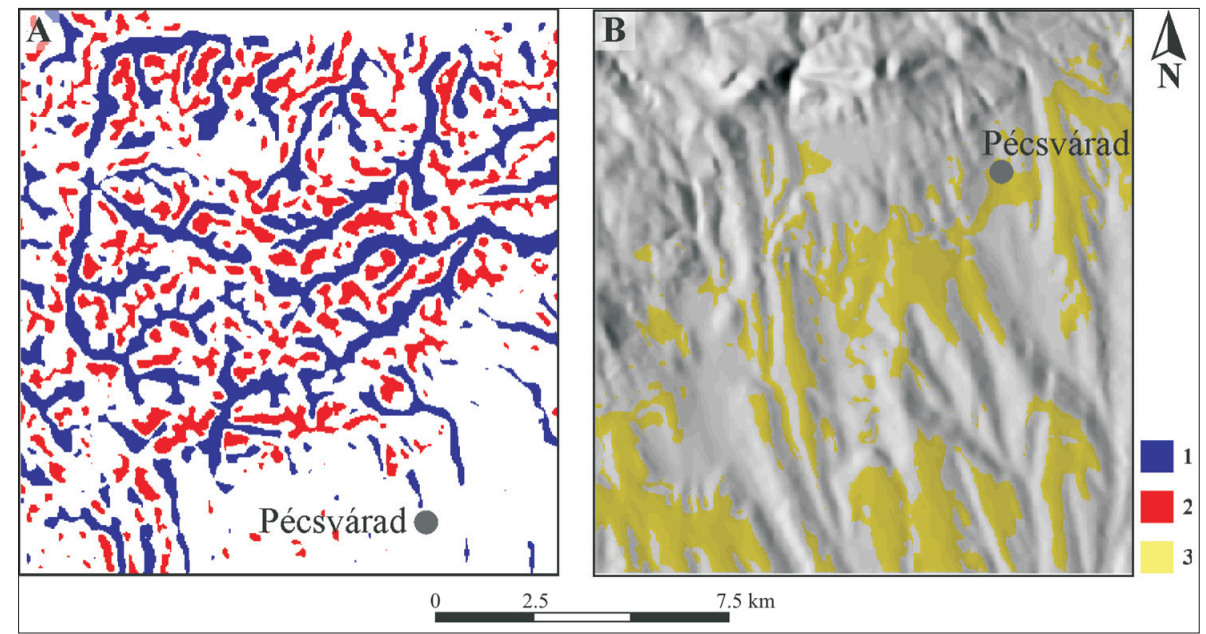

Fig. 8. The valley network and ridge lines of the Eastern Mecsek Mountains (A), and the piedmont-like surfaces stretched on the shaded relief map of EU-DEM (B) based on the TPI map. $-1=$ valleys; $2=$ mountain tops, high ridges; 3 = piedmont-like surfaces 
like surfaces on the shaded relief map it can be declared that these are in a good agreement with the former piedmont forms, that were fragmented into lower interfluves by the consequent streams. Evolution of the piedmont region can be also explained using the calculated landform map: basins and submountain depressions (Bogád, Ellend and Pécsvárad) affected by Mecsekalja dislocation zone and transversally dissected piedmont surfaces are also detected.

\section{Conclusions}

The EU-DEM and the two other satellite-based DSMs had different elevation error over the study area, so analysing the error statistics and distribution is recommended before applying. Then the horizontal misfit of the models was confirmed and corrected by comparing the location of peaks. The calculated effective resolution showed that the models horizontal spacing is over-estimated, resulting greater storage capacity requirements. The effective resolution, visual comparison and correlation between the elevation datasets suggest that the EU-DEM has more similarity to the SRTM, probably because of the smoothing used for the fusion method.

Lowering elevation data or uplifting the surface according to mean errors of the categories treated the height differences caused by the land cover. Based on the results, it seems to be a time-saving solution to alter a larger study area with values determined for smaller, but representative reference sites. The used denoising method also improved the models, and it is suggested even for just visualizing goals.

The visual and statistical validation process showed that there are still some errors that need to be corrected, and the parameterization of the denoising method could be more precise, but in all the models are suitable for geomorphologic studies. This was tested by creating the TPI-based geomorphometric map and analysing the results connected to the geomorphic issues of this particular area. Dissected piedmont-like surfaces and the radial horst ranges and the tectonic valley network were recognized.

Acknowledgements: This research was supported by the European Union and the State of Hungary, co-financed by the European Social Fund in the framework of TÁMOP-4.2.4.A/ 2-11/1-2012-0001 'National Excellence Program'. 


\section{REFERENCES}

Ádám, L., Marosi, S. and Szilárd, J. 1981. A Dunántúli-dombság (The Transdanubian Hills). Magyarország tájföldrajza 4. (Landscape Geography of Hungary 4). Budapest, Akadémiai Kiadó, 704 p.

Aguilar, F.J., AgüEra, F. and Aguilar, M.A. 2007. A theoretical approach to modelling the accuracy assessment of digital elevation models. Photogrammetric Engineering \& Remote Sensing 73. (12): 1367-1379.

ASTER GDEM database. http://www.jspacesystems.or.jp/ersdac/GDEM/E/index.html

ASTER GDEM Validation Team 2009. ASTER global DEM validation summary report. METI \& NASA. 28. https://lpdaac.usgs.gov/sites/default/files/public/aster/docs/ASTER_GDEM_ Validation_Summary_Report.pdf

ASTER GDEM Validation Team (Tachikawa, T., Kaku, M., Iwasaki, A., Gesch, D., Oimoen, M., Zhang, Z., Danielson, J., Krieger, T., Curtis, B., Hasse, J., Abrams, M., Crippen, R., Carabajal, C. and Meyer, D.) 2011. ASTER Global Digital Elevation Model Version 2 - Summary of Validation Results. 26. https://lpdaacaster.cr.usgs.gov/GDEM/Summary_ GDEM2_validation_report_final.pdf

Bashrield, A. and Keim, A. 2011. Continent-wide DEM Creation for the European Union. $34^{\text {th }}$ International Symposium on Remote Sensing of Environment. The GEOSS Era: Towards Operational Environmental Monitoring. Sydney, Australia 10-15 April 2011 http://www. isprs.org/proceedings/2011/isrse-34/211104015Final00143.pdf

BIvAND, R. 2013. Package spgrass6: Interface between GRASS 6 and R. R package version 0.8-3. http://cran.r-project.org/web/packages/spgrass6/spgrass6.pdf

Bolch, T., Kamp, U. and Olsenholler, J. 2005. Using ASTER and SRTM DEMs for studying geomorphology and glaciation in high mountain areas. In New Strategies for European Remote Sensing. Ed. Oliuc, M. Proceedings, $24^{\text {th }}$ Annual Symposium European Association of Remote Sensing Laboratories (EARSeL), 25-27 May 2004, Dubrovnik, Croatia. Rotterdam, Millpress, 119-127.

Borders of Hungarian micro regions. http://www.novenyzetiterkep.hu/?q=magyar/node/407

Borders of Natura 2000 areas. http://www.eea.europa.eu/data-and-maps/data/natura-4\#tabgis-data

Bubenzer, O. and Bolten, A. 2008. The use of new elevation data (SRTM/ASTER) for the detection and morphometric quantification of Pleistocene megadunes (draa) in the eastern Sahara and the southern Namib. Geomorphology 102. 221-231

Büttner, G., Kosztra, B., Maucha, G. and Pataki, R. 2012. Implementation and achievements of CLC2006. 65. http://www.eea.europa.eu/data-and-maps/data/corine-land-cover-2006raster-2/clc-final-report/clc-final-report/at_download/file

CLC2006 database. http://www.eea.europa.eu/data-and-maps/data/clc-2006-vector-data-version-2\#tab-metadata

DrĂGUȚ, L. and EISANK, C. 2011. Object representations at multiple scales from digital elevation models. - Geomorphology 129. 183-189.

DrĂGUȚ, L. and EISANK, C. 2012. Automated object-based classification of topography from SRTM data. Geomorphology 141-142. 21-33.

DrĂGUȚ, L., EisAnK, C. and Strasser, T. 2011. Local variance for multi-scale analysis in geomorphometry. Geomorphology 130.162-172.

EngleR, P. and MéLYKúTI, G. 2000. Az 1:10 000 méretarányú topográfiai térképek domborzatának ellenőrzése új mérési eredmények felhasználásával (Control of the relief of topographic maps in scale 1:10,000 using results of new measurement). X. Országos Térinformatikai Konferencia, Szolnok. 
EU-DEM dataset. http://epp.eurostat.ec.europa.eu/portal/page/portal/gisco_Geographical_information_maps/geodata/digital_elevation_model

EU-DEM Metadata. http://www.eea.europa.eu/data-and-maps/data/eu-dem\#tab-metadata

FÁBián, Sz.Á., Schweitzer, F. and VARGA, G. 2005. A Pécsi-víz völgyének kialakulása és kora. In $A$ földrajz dimenziói: Tiszteletkötet a 65 éves Tóth Józsefnek. Eds. DövénYI, Z. and Schwertzer, F. Budapest, MTA Földrajztudományi Kutatóintézet, 461-472.

Farr, T.G., Rosen, P.A., Caro, E., Crippen, R., Duren, R., Hensley, S., Kobrick, M., Paller, M., Rodriguez, E., Roth, L., Seal, D., Shaffer, S., Shimada, J., Umland, J., Werner, M., Oskin, M., Burbank, D. and Alsdorf, D. 2007. The Shuttle Radar Topography Mission. Reviews in Geophysics 45. 1-33.

ForkUor, G. and MAATHUIS, B. 2012. Comparison of SRTM and ASTER Derived Digital Elevation Models over Two Regions in Ghana - Implications for Hydrological and Environmental Modeling. In Studies on Environmental and Applied Geomorphology. Eds. Piacentini, T. and Miccadei, E., Rijeka, InTech, 219-240.

FreY, H. and PAUL, F. 2012. On the suitability of the SRTM DEM and ASTER GDEM for the compilation of topographic parameters in glacier inventories. International Journal of Applied Earth Observation and Geoinformation. 18. 480-490.

Gichamo, T.Z., Popescu, I., Jonoski, A. and Solomatine, D. 2012. River cross-section extraction from the ASTER global DEM for flood modeling. Environmental Modelling \& Software 31. $37-46$.

Grohmann, C.H. and Sawakuchi, A.O. 2013. Influence of cell size on volume calculation using digital terrain models: a case of coastal dune fields. Geomorphology 180-181. 130-136.

GuTH, P.L. 2010. Geomorphometric comparison of ASTER GDEM and SRTM. Special joint symposium of ISPRS Technical Commission IV \& AutoCarto in conjunction with ASPRS/CaGIS 2010 Fall Specialty Conference, November 15-19, 2010 Orlando, Florida

HaAs, J. 2012. Alpine evolution. In Geology of Hungary. Ed. HAAs, J., Budapest, Eötvös University Press, 118-136.

Hengl, T. and Reuter, H. 2011. How accurate and usable is GDEM? A statistical assessment of GDEM using LiDAR data. In Geomorphometry - Proceedings. Eds. Hengl, T., Evans, S.I., Wilson, J.P. and Gould, M., CA, USA, 7-11 September 2011, Redlands, 45-48.

Hirano, A., Welch, R. and LAng, H. 2003. Mapping from ASTER stereo image data: DEM validation and accuracy assessment. ISPRS Journal of Photogrammetry and Remote Sensing 57. 356-370.

Hofton, M., Dubayah, R., Blair, J. B. and Rabine, D. 2006. Validation of SRTM elevations over vegetated and non-vegetated terrain using medium footprint Lidar. Photogrammetric Engineering and Remote Sensing 72. 279-285.

Jacobsen, K. and PAssini, R. 2009. Analysis of ASTER GDEM Elevation Models. International Archieves of the Photogrammetry, Remote Sensing and Spatial Sciences 38. Calgary, 2010, 6 S.

Jenness, J. 2006. Topographic Position Index (TPI) v.1.2 http://www.jennessent.com/downloads/ TPI_Documentation_online.pdf

Кё̈̈в, A. 2005. Combination of SRTM3 and repeat ASTER data for deriving alpine glacier flow velocities in the Bhutan Himalaya. Remote Sensing of Environment 94. 463-474

KarkeE, M., Steward, B. and Aziz, S. 2008. Improving quality of public domain digital elevation models through data fusion. Biosystems Engineering 101. 293-305.

Kenyeres, A., Sacher, M., Ihde, J., Denker, H. and Marti, U. 2010. EUVN Densification Action. Final report. 19 p. http://www.bkg.bund.de/geodIS/EVRS/SharedDocs/Downloads/ Publications/EUVN-DA__FinalReport,templateId=raw, property=publicationFile.pdf/ EUVN-DA_FinalReport.pdf 
Kovács, I.P., Bugya, T., FÁBIÁN, Sz.Á. and SchweitZer, F. 2013. Review on denudation levels of the Western Mecsek Mountains (SW Transdanubia, Hungary). Studia Geomorphologica Carpatho Balcanica 47.(1): 49-67.

Kovács, M. 2013. Egy Pécs közeli vízfolyás vizsgálata geomorfológiai módszerekkel (The analysis of a drainage basin near Pécs with geomorphic methods). In A földtudományi kutatások új aspektusai. Eds. BALogh, R. and Sснмidt, P., Pécs, Publikon Kiadó, 27-32.

Li, P., Shi, C., Li, Z., Muller, J.-P., Drummond, J., Li, X., LI, T., Li, Y. and Liu, J. 2012. Evaluation of ASTER GEM Ver2 using GPS measurements and SRTM Ver4.1 in China. ISPRS Annals of the Photogrammetry, Remote Sensing and Spatial Information Sciences I-4. 181-186.

Lovász, Gy. (ed.) 1977. Baranya megye természeti földrajza (Physical geography of Baranya county). Pécs, Baranya Megyei Levéltár, 46-67, 163-188.

Magyar, I., Geary, D.H. and Muller, P. 1999. Paleogeographic evolution of the Late Miocene Lake Pannon in Central Europe. Palaeogeography Palaeoclimatology Palaeoecology 147. (3-4): 151-167.

Mukherjee, S., Joshi, P.K., Ghosh, A., Garg, R.D. and Mukhopadhyay, A. 2013. Evaluation of vertical accuracy of open source Digital Elevation Model (DEM). International Journal of Applied Earth Observation and Geoinformation 21. 205-217

Nagymarosy, A. and Hámor, G. 2012. Genesis and Evolution of the Pannonian Basin. In Geology of Hungary. Ed. HaAs, J., Budapest, Eötvös University Press, 49-200.

Neteler, M. 2005. SRTM and VMAP0 data in OGR and GRASS. GRASS Newsletter 3. 2-6.

PAUL, F. 2008. Calculation of glacier elevation changes with SRTM: is there an elevation dependent bias? Journal of Glaciology 54. (188.) 945-496.

PÉCsI, M. 1963. Hegylábi (pediment) felszínek a magyarországi középhegységekben (Pediment surfaces in the Hungarian mountain ranges). Földrajzi Közlemények 87. (3): 195-212.

PÉCSI, M. 1985. Domborzatminősítő térképek (Maps for qualification of relief). In Mérnökgeomorfológiai térképezés (Engineering geomorphological mapping). Eds. ÁDÁM, L. and PÉCsI, M., Budapest, MTA Földrajztudományi Kutatóintézet, 7-14.

Pécsi, M., Gerei, L., Schweitzer, F., Scheuer, Gr. and Márton, P. 1987. Loess and paleosol sequences in Hungary reflecting cyclic climatic deterioration in the Late Cenozoic. In Pleistocene environment in Hungary. Ed. PÉcsI, M. Contribution of the INQUA Hungarian National Committee to the XII ${ }^{\text {th }}$ INQUA congress: Ottawa-Budapest, Geographical Research Institute, Hungarian Academy of Sciences, $42 \mathrm{p}$.

Pécsi, M., Gerei, L., Schweitzer, F., Scheuer, Gy. and Márton, P. 1988. Ciklikus éghajlatváltozás és rosszabbodás visszatükröződése a magyarországi löszök és eltemetett talajok sorozatában (The reflection of cyclic climate change and worsening from the Hungarian loess and buried paleosoil series). Idójárás (Quarterly Journal of The Hungarian Meteorological Service) 92. (2-3): 75-86.

Reuter, H.I., Nelson, A., Strobl, P., Mehl, W. and Jarvis, A. 2009. A First Assessment of Aster Gdem Tiles for Absolute Accuracy, Relative Accuracy and Terrain Parameters. IEEE International Geoscience and Remote Sensing Symposium. 240-243.

Robinson, N., Regetz, J. and Guralnick, R.P. 2014. EarthEnv-DEM90: A nearly-global, void-free, multi-scale smoothed, $90 \mathrm{~m}$ digital elevation model from fused ASTER and SRTM data. ISPRS Journal of Photogrammetry and Remote Sensing 87. 57-67.

Rodriguez, E., Morris, C.S., Belz, J.E., Chaplin, E.C., Martin, J.M., Daffer, W. and Hensley, S. 2005. An Assessment of the SRTM Topographic Products. Pasadena, CA USA, Jet Propulsion Laboratory, $143 \mathrm{p}$. 
SaAdat, H., Bonnell, R., Sharifi, F., Mehuys, G., Namdar, M. and Ale-Ebrahim, S. 2008. Landform classification from a digital elevation model and satellite imagery. Geomorphology 100. 453-464.

SADEQ, H., DRUMmond, J. and Li, Z. 2012. Evaluation of ASTER GDEM v.2 using GPS checkpoints, OSGB DEM values and photogrammetrically derived DEMs. ISPRS Annals of the Photogrammetry, Remote Sensing and Spatial Information Sciences. Vol. I-4, XXII ${ }^{\text {nd }}$ ISPRS Congress, 25 Aug.-1 Sept. 2012, Melbourne, Australia, 295-300.

Schweitzer, F. 1997. On late Miocene - early Pliocene desert climate in the Carpathian Basin. In Geomorphology and changing environments in Central Europe. Eds. BREMER, H. and Lóczy, D. IAG European Regional Geomorphological Conference, Hungary, April 1996. Stuttgart, Gebrüder Borntraeger, 37-43. (Zeitschrift für Geomorphologie Supplementband 110.)

Sebe, K., Csillag, G. and Konrád, Gy. 2008. The role of neotectonics in fluvial landscape development in the Western Mecsek Mountains and related foreland basin (SE Transdanubia, Hungary). Geomorphology 102. 55-67.

Seres, A. and Doвos, E. 2009. Területhasználati térkép készitése müholdfelvételek alapján az SRTM magasságmodell pontositására (Preparation of landuse map based on satellite images to clarify SRTM elevation model), HunDEM2009, Konferencia és Kerekasztal Kiadv., Miskolc, University of Miskolc, 15 p.

Siart, C., Bubenzer, O. and Eitel, B. 2009. Combining digital elevation data (SRTM/ASTER), high resolution satellite imagery (Quickbird) and GIS for geomorphological mapping: A multi-component case study on Mediterranean karst in Central Crete. Geomorphology 112. 106-121.

SRTM 90 m Digital Elevation Database v4.1. http://www.cgiar-csi.org/data/srtm-90m-digital-elevation-database-v4-1

SRTM dataset. http://srtm.csi.cgiar.org/SELECTION/inputCoord.asp

Stevenson, J.A., Sun, X. and Mitchell, N.C. 2010. Despeckling SRTM and other topographic data with a denoising algorithm. Geomorphology 114. 238-252.

Sun, X., Rosin, P.L., Martin, R.R. and Langbein, F.C. 2007. Fast and Effective FeaturePreserving Mesh Denoising. IEEE Transactions on Visualisation and Computer Graphics 13. 925-938.

Sumandana, E., Kawamura, K., Sakuno, Y., Kustiyanto, E. and Raharjo, B. 2012. Evaluation of ASTER GDEM2 in Comparison with GDEM1, SRTM DEM and TopographicMap-Derived DEM Using Inundation Area Analysis and RTK-dGPS Data. Remote Sensing 4. 2419-2431.

Szabó, G. 2011. Az ASTER GDEM adatbázis pontosságának vizsgálata egy hazai mintaterületen (Accuracy assesment of the ASTER GDEM dataset over a Hungarian study area). In Az elmélet és a gyakorlat találkozása a térinformatikában II. Ed. LóKI, J., Konferenciakötet. Debrecen, Kapitális Nyomdaipari Kft. 421-427.

Szabó, G. and Szabó, Sz. 2010. A Shuttle Radar Topography Mission (SRTM) során nyert adatbázis pontosságának vizsgálata hazai mintaterületeken (Checking the accuracy of the database collected during the Shuttle Radar Topography Mission [SRTM] in Hungarian sample areas). Geodézia és Kartográfia 62. 31-35.

Szabó, G., Mecser, N. and KariKa, A. 2013. Assessing data quality of remotely-sensed DEMs in a Hungarian sample area. Acta Geographica Debrecina Landscape and Environment 7. 42-47.

TAKEDA, R. and TAKEUCHI, W. 2010. Towards DTM generation from SRTM3 and ASTER GDEM in hilly terrain using wavelets. $31^{\text {st }}$ Asian conference on remote sensing (ACRS). Nov. 2 2010. Hanoi, Vietnam. 
Urai, M., TAchikawa, T. and Fujisada, H. 2012. Data acquisition strategies for Aster Global DEM generation. ISPRS Annals of the Photogrammetry, Remote Sensing and Spatial Information Sciences, Vol. I-4, XXIII IS ISPRS Congress, 25 Aug.-1 Sept. 2012, Melbourne, Australia, 199-202.

VÁGó, J. and Hegedús, A. 2011. DEM based examination of pediment levels: a case study in Bükkaja, Hungary. Hungarian Geographical Bulletin 60. (1): 25-44.

Van Asselen, S. and Seijmonsbergen, A.C. 2006. Expert-driven semi-automated geomorphological mapping for a mountainous area using a laser DTM. Geomorphology 78. 309-320.

Weiss, A. 2001. Topographic Position and Landforms Analysis. A poster for the Conference. http://www.jennessent.com/downloads/tpi-poster-tnc_18x22.pdf

WinkLER, P. 2007. Magyarország digitális ortofotó programjai és az 1:10 000 országos vektoros adatbázis (The digital ortophoto projects of Hungary and the 1:10,000 scale vector dataset). In Földminôsités, földértékelés és földhasználati információ. Eds. TóTH, T., Tóтн, G., Németh, T. and GaÁL, Z., Keszthely-Budapest, HAS CAR, 161-168.

WinkLer, P., Iván, Gy., KAY, S., SPruyt, P. and Zielinski, R. 2006. Ürfelvételekből származtatott digitális felületmodell minőségének ellenőrzése a nagyfelbontású digitális domborzatmodell alapján (Quality checking of DSM derived from satellite data (SPOT and SRTM) on the base of Hungarian high resolution DEM). Geodézia és Kartográfia 61. 22-31.

Zhao, S., Cheng, W., Zhou, C., Chen, X., Zhang, S., Zhou, Z., Liu, H. and Chai, H. 2011. Accuracy assessment of the ASTER GDEM and SRTM3 DEM: an example in the Loess Plateau and North China Plain of China. International Journal of Remote Sensing 32. 8081-8093. 


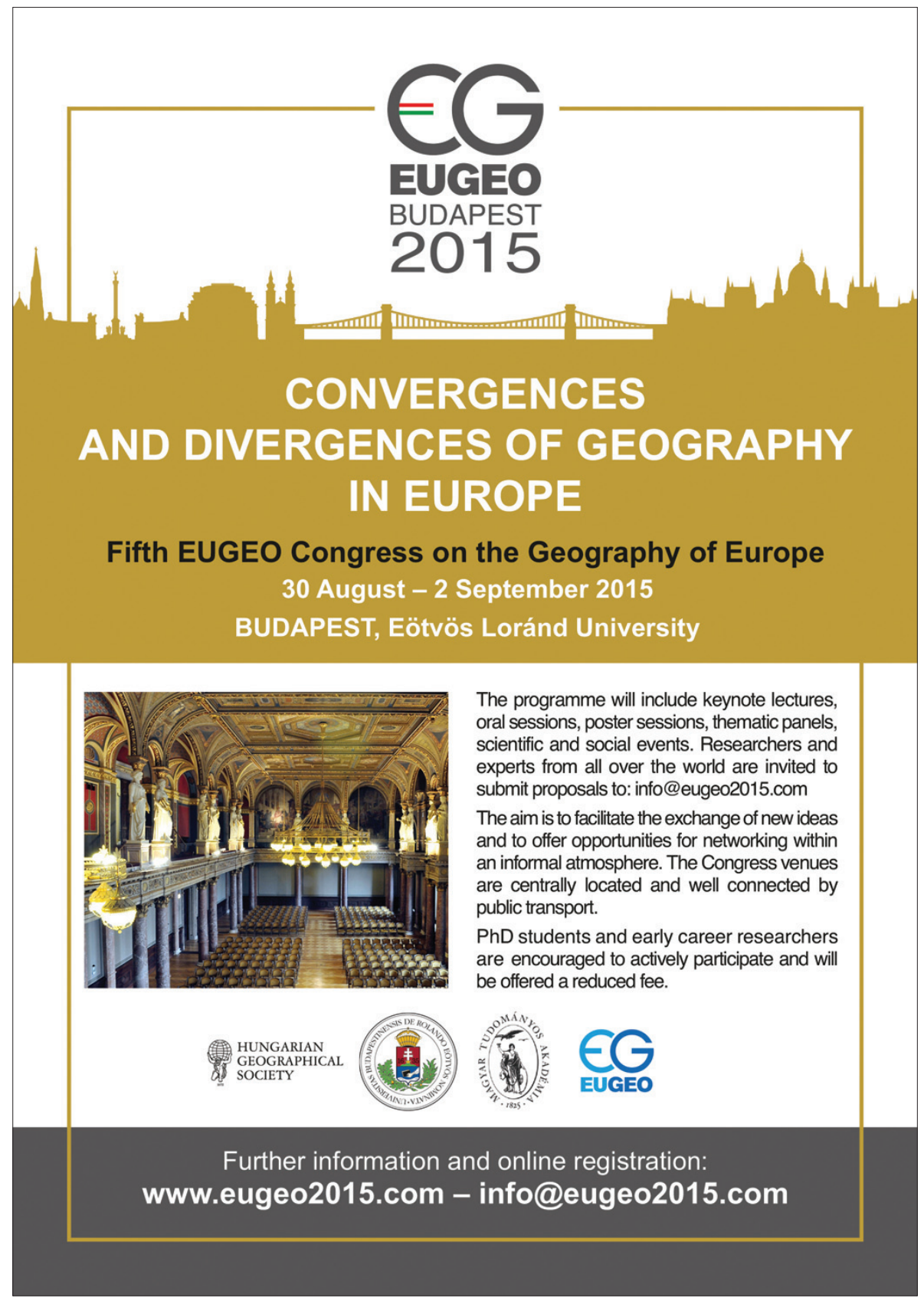

